\title{
ABNORMAL GLYCINE METABOLISM IN RHEUMATOID ARTHRITIS
}

\author{
By H. M. LEMON, ${ }^{1}$ W. H. CHASEN, ${ }^{2}$ ANd J. M. LOONEY ${ }^{3}$ \\ (From the Arthritis Clinic, Boston Regional Office, Veterans Administration, and the Depart- \\ ments of Medicine and Biochemistry, Boston University School of Medicine, \\ Boston, Mass.)
}

(Submitted for publication April 23, 1952; accepted August 15, 1952)

Connective tissue is considered to be composed of tightly folded polypeptide chains, resting in an extracellular amorphous ground substance consisting of polymerized muco-polysaccharides. As a result of the pioneering investigations of Meyer (1) and Duran-Reynals (2), considerable investigation has been carried out concerning alterations in composition and permeability of the ground substance in diseases affecting connective tissues (3). Alterations in the polypeptide chains responsible for the tensile strength and elasticity of connective tissue, however, have not yet been adequately studied in these diseases, nor is there any information available concerning the factors responsible for maintaining the integrity of this widely prevalent extracellular protein network. Methods suitable for clinical investigation have been lacking for investigation of this problem. We wish to report an adaptation of the hippuric acid liver function test devised by Quick (4), which has revealed in patients with active rheumatoid arthritis abnormal metabolism of at least one of the major amino acid components of collagen. These patients fail to maintain their serum glycine within 15 per cent of the fasting value after the administration of $1.77 \mathrm{gm}$. sodium benzoate intravenously.

The basis for our observations rests upon the unique chemical composition of the proteins, collagen and elastin. Glycine constitutes 22.8 to 27.6 per cent by weight of these substances, accounting for approximately one-third of the total

\footnotetext{
1 Consultant, internal medicine research, Boston Regional Office, Veterans Administration; assistant Professor of Medicine, Boston University School of Medicine.

2 Chief, Arthritis Clinic, Boston Regional Office, Veterans Administration.

3 Chief of Laboratory, Boston Regional Office, Veterans Administration; Research Professor of Biochemistry, Boston University School of Medicine.
}

amino acid residues in these proteins (5). The glycine content of these proteins is unlike that of any other human extracellular (see Table I) or intracellular proteins whose composition has been described (6). Any widespread increase in collagen synthesis in the body might therefore be reflected in a considerable increase in the requirements of this amino acid. Although glycine is not an essential amino acid, its rate of synthesis is so limited that dietary supplementation is necessary in birds where large amounts of collagen are needed for feather development (7). Furthermore, excessive excretion of glycine as hippurate has been shown to limit body growth in rats (8).

During fasting, the normal serum glycine level of 2.0 to $3.0 \mathrm{mg}$. per cent is chiefly maintained by diffusion of "readily available" glycine stored in extra-hepatic tissues, since the liver is continuously de-aminating amino acids in circulation. Glycine may also be synthesized in the liver, along with other non-essential amino acids (9). About two-thirds of the glycine conjugated with benzoic acid in the liver, in the hippuric acid excretion test devised by Quick, comes from endogenous sources (10). Serine, sarcosine, and glycolic acid have been shown to contribute to the formation of glycine (11-15). Since a marked reduction in the rate of hippurate formation may occur in some cases of acute or advanced rheumatoid arthritis (16-19), we became interested in learning whether this represented merely reduced liver function, or decreased supplies of "readily available" glycine in peripheral tissues, which prevented the conjugating activity of the liver from acting at full capacity. Estimation of the concentration of serum glycine during the rapid hepatic formation and renal excretion of glycine-benzoic acid conjugates (hippuric acid) was therefore carried out to determine the relative availability of free glycine in cellular reservoirs, and in extracellular 
TABLE I

Glycine and alanine content of various proteins

\begin{tabular}{l|c|c}
\hline \hline & $\begin{array}{c}\text { Glycine } \\
\text { gm. per 100 } \\
\text { gm. prot. }\end{array}$ & $\begin{array}{c}\text { Alanine } \\
\text { gm. per 100 } \\
\text { gm. prot. }\end{array}$ \\
\cline { 1 - 2 } $\begin{array}{c}\text { A. Intracellular proteins } \\
\text { 1. Muscle }\end{array}$ & $2-5$ & 4 \\
2. Liver & 8.5 & 4.7 \\
3. Human hemoglobin & 4.2 & 9.5 \\
\hline B. Extracellular proteins & & \\
1. Collagen & $22.8-23.1$ & 8.1 \\
2. Elastin & $24-27.6$ & $0-6$ \\
3. Human serum albumin & 1.6 & \\
4. Human serum globulin & 5 & 2 \\
5. Fibrin & $5.2-5.4$ & 4 \\
6. Bence-Jones protein & 2 & 5 \\
7. Keratin (human hair) & 4.5 & 1.5 \\
8. Insulin & $4.4-4.6$ & $2.7-4.5$ \\
9. Human casein & 0 & 2.1 \\
10. Human lactalbumin & 0 & 2.7 \\
\hline
\end{tabular}

Values selected from Block and Bolling, VII, pp. 358$361(6)$.

(Omission of decimal fractions indicates approximate nature of reported values.)

depots such as collagen and elastin. Simultaneous estimation of serum alanine was carried out as a control, since this amino acid has an entirely different frequency distribution in tissue proteins, and does not directly participate in the detoxification of benzoic acid (Table I). Alanine synthesis is very readily performed in man since glutamic and pyruvic acid contribute to its formation.

\section{METHODS}

Most of the patients selected for study were ambulatory, gainfully employed and in nutritional balance. In most cases, several years had elapsed since any previous hospitalization. Serum was obtained from fasting patients for bilirubin determination (20), bromsulphalein retention 45 minutes after injection of $5 \mathrm{mg} . / \mathrm{Kg}$. (21), alkaline phosphatase (22), cholesterol ester partition (23, $24)$, total serum protein and A/G (25), thymol turbidity (26), cephalin flocculation (27), and for amino acid determination. In addition to routine urinalysis, fractional phenolsulfonephthalein excretion was carried out on most patients, as a check on renal function.

The modified hippuric acid test of Quick was carried out as follows: After a 12-hour fast, and after the patient had emptied his bladder, an initial venous blood sample was obtained, and $1.77 \mathrm{gm}$. of sodium benzoate was injected intravenously within a 5-minute period. All urine was collected as separate specimens for the first and second hours after injection, and a second blood sample was obtained at one hour and sometimes at longer intervals. Precautions were taken to ensure an adequate urine flow, usually by ingestion of 200 to $400 \mathrm{cc}$. of water prior to injection, or a cup of black coffee. Serum glycine and alanine were determined on aliquots of identical serum specimens. The methods of Alexander were used for glycine and alanine estimation $(28,29)$, and those of Weichselbaum were used for determination of hippuric acid excretion (30).

The arthritic cases have been classified in Stages I to IV according to the classification of Steinbrocker as adopted by the New York Rheumatism Association (31).

\section{RESULTS}

At present, 54 patients with rheumatoid arthritis in all degrees of activity and stages of disease have been studied, as well as 41 control patients, the majority of whom had hypertrophic osteo-arthritis, post-traumatic arthritis, gout or metastatic cancer (Tables II, III). Thirty-six of the 41 control patients revealed serum glycine levels which either did not change after sodium benzoate administration, or declined less than 15 per cent at the end of one hour after injection

TABLE II

Initial response of serum glycine to benzoate administration in various clinical conditions

\begin{tabular}{|c|c|c|}
\hline Diagnosis & $\begin{array}{l}\text { No. of cases } \\
\text { with } 15 \text { per } \\
\text { cent or } \\
\text { greater re- } \\
\text { duction } \\
\text { from initial } \\
\text { level }\end{array}$ & $\begin{array}{l}\text { No. of cases } \\
\text { with less } \\
\text { than } 15 \text { per } \\
\text { cent reduc- } \\
\text { tion from } \\
\text { initial level }\end{array}$ \\
\hline $\begin{array}{l}\text { A. Control patients } \\
\text { Decompensated hepatic cirrhosis } \\
\text { Metastatic adenocarcinoma } \\
\text { Traumatic arthritis } \\
\text { Hypertrophic osteo-arthritis } \\
\text { Gouty arthritis } \\
\text { Psychogenic rheumatism and psychoneu- } \\
\text { rosis } \\
\text { Miscellaneous non-arthritic problems } \\
\text { such as spondylolysis, calcified bursa, } \\
\text { healed spinal fusion, etc. } \\
\text { Bronchial asthma } \\
\text { Postoperative hemorrhoidectomy } \\
\text { Lobar pneumonia, convalescent } \\
\text { Chronic dermatitis } \\
\text { Meniere's syndrome } \\
\text { Total of control patients }\end{array}$ & $\begin{array}{l}\mathbf{1} \\
\mathbf{2} \\
\mathbf{1} \\
\mathbf{1}\end{array}$ & $\begin{array}{r}5 \\
3 \\
12 \\
1 \\
3 \\
5 \\
2 \\
1 \\
1 \\
2 \\
1 \\
36\end{array}$ \\
\hline $\begin{array}{l}\text { B. Rheumatoid arthritis, peripheral joints } \\
\text { Stage I } \\
\text { Stage II } \\
\text { Stage III-IV } \\
\text { C. Rheumatoid spondylitis } \\
\text { Stage I } \\
\text { Stage II } \\
\text { Stage III-IV } \\
\text { Total of rheumatoid patients, including } \\
\text { both active and inactive phases of } \\
\text { disease }\end{array}$ & $\begin{array}{r}10 \\
5 \\
2 \\
3 \\
13 \\
2 \\
\end{array}$ & $\begin{array}{l}8 \\
3 \\
1 \\
0 \\
\mathbf{4} \\
\mathbf{3} \\
\end{array}$ \\
\hline $\begin{array}{l}\text { D. Rheumatic heart disease } \\
\text { Active rheumatic fever recurrence } \\
\text { Inactive } \\
\text { E. Other diseases involving collagen } \\
\text { Reiter's syndrome, acute } \\
\text { Chronic discoid lupus erythematosus } \\
\text { Spontaneous postoperative wound de- } \\
\text { hiscence and cortical ovarian fibrosis } \\
\text { (Chiari-Frommel syndrome) }\end{array}$ & $\begin{array}{l}1 \\
0 \\
1 \\
0\end{array}$ & $\begin{array}{l}2 \\
2 \\
0 \\
1\end{array}$ \\
\hline
\end{tabular}

* Nine of these 19 patients on subsequent tests showed a reduction in serum glycine of more than 15 per cent. 
TABLE III

Hippurate excretion and serum glycine response in arthritic and non-arthritic patients

\begin{tabular}{|c|c|c|c|c|c|c|}
\hline Diagnosis & $\begin{array}{l}\text { No. } \\
\text { pts. }\end{array}$ & $\begin{array}{l}\text { No. } \\
\text { obs. }\end{array}$ & $\begin{array}{l}\text { Mean first hour } \\
\text { hippurate (ex- } \\
\text { pressed as gm. } \\
\text { benzoic acid) }\end{array}$ & $\begin{array}{c}\text { Mean per cent } \\
\text { change in serum } \\
\text { glycine }\end{array}$ & $\begin{array}{l}\text { Standard } \\
\text { error of } \\
\text { difference } \\
\text { between } \\
\text { means of } \\
\text { control and } \\
\text { test series of } \\
\text { glycine ob- } \\
\text { servations }\end{array}$ & $\begin{array}{l}t \text { value of } \\
\text { signifi- } \\
\text { cance* }\end{array}$ \\
\hline $\begin{array}{l}\text { A. Control patients without bone or joint disease } \\
\text { B. Control patients with radiologic evidence of joint } \\
\text { pathology other than rheumatoid arthritis } \\
\text { C. Control patients with radiologic evidence of } \\
\text { osseous pathology other than rheumatoid arthritis } \\
\text { (6 met. carcinomas, } 1 \text { Paget's disease) }\end{array}$ & $\begin{array}{r}16 \\
18 \\
7\end{array}$ & $\begin{array}{r}17 \\
19 \\
9\end{array}$ & $\begin{array}{c}0.760 \pm 0.282 \\
\text { S.E. } 0.071 \\
0.789 \pm 0.215 \\
\text { S.E. } 0.049 \\
0.715 \pm 0.340\end{array}$ & $\begin{array}{c}-5.1 \pm 6.7 \\
\text { S.E. } 1.7 \\
-9.3 \pm 7.2 \\
\text { S.E. } 1.7 \\
-7.5 \pm 11.7\end{array}$ & & \\
\hline Total of controls & 41 & 45 & $\begin{array}{l}0.764 \pm 0.272 \\
\text { S.E. } 0.041\end{array}$ & $\begin{array}{l}-7.4 \pm 8.4 \\
\text { S.E. } 1.2\end{array}$ & & \\
\hline $\begin{array}{l}\text { D. Patients with Stage I rheumatoid arthritis (with- } \\
\text { out radiologic signs of disease except soft tissue } \\
\text { swelling) }\end{array}$ & 21 & 34 & $\begin{array}{l}0.913 \pm 0.334 \\
\text { S.E. } 0.058\end{array}$ & $\begin{array}{l}-18.9 \pm 14.8 \\
\text { S.E. } 2.5\end{array}$ & $2.8 \%$ & 4.07 \\
\hline $\begin{array}{l}\text { E. Patients with Stage II rheumatoid arthritis (with } \\
\text { radiologic evidence of joint pathology but no } \\
\text { deformity) }\end{array}$ & 25 & 46 & $\begin{array}{c}0.852 \pm 0.276 \\
\text { S.E. } 0.041\end{array}$ & $\begin{array}{c}-15.4 \pm 13.1 \\
\text { S.E. } 1.9\end{array}$ & $2.3 \%$ & 3.47 \\
\hline $\begin{array}{l}\text { F. Patients with Stage III-IV rheumatoid arthritis } \\
\text { (with joint deformity and/or total disability) } \\
\text { G. Miscellaneous patients with other diseases of } \\
\text { collagen }\end{array}$ & $\begin{array}{l}8 \\
8\end{array}$ & $\begin{array}{r}36 \\
8\end{array}$ & $\begin{array}{l}0.778 \pm 0.308 \\
\text { S.E. } 0.056 \\
0.775 \pm 0.238\end{array}$ & $\begin{array}{l}-15.7 \pm 14.9 \\
\text { S.E. } 2.5 \\
-13.4 \pm 11.9\end{array}$ & $\begin{array}{l}2.8 \% \\
4.4 \%\end{array}$ & $\begin{array}{l}2.99 \\
1.36\end{array}$ \\
\hline
\end{tabular}

* When $t$ equals or exceeds 3.0, differences in mean values attributable to chance alone would occur less than once in 370 sets of observations.

(Figure 1). A decline of serum glycine exceeding 15 per cent of the initial fasting level was present in five of the control patients, nearly all of whom had clinical disease of one type or another. Two patients had proven metastatic carcinoma; one was in remission following radiation and testosterone therapy. A third patient also developed a positive test with the progression of hepatic metastases of mammary adenocarcinoma. One patient suffered from decompensated portal cirrhosis with ascites, and another had post-traumatic arthritis of the acetabulum secondary to malposition resulting from an old femoral neck fracture. One patient had roentgenologic evidence of hypertrophic osteoarthritis of the spine, with a persistently normal sedimentation rate. Patients recovering from extensive infections or surgical procedures were among the few control patients whose reduction in serum glycine following benzoate administration approached but did not exceed 15 per cent.

Thirty-five of the unselected 54 patients with rheumatoid involvement showed, on initial examination, a decline of serum glycine greater than 15 per cent of the fasting value at one hour, similar to that seen in Figure 1. Twenty-eight of 29 of

TYPICAL RESPONSE OF SERUM GLYCINE Q ALANINE TO INJECTION OF SODIUM BENZOATE

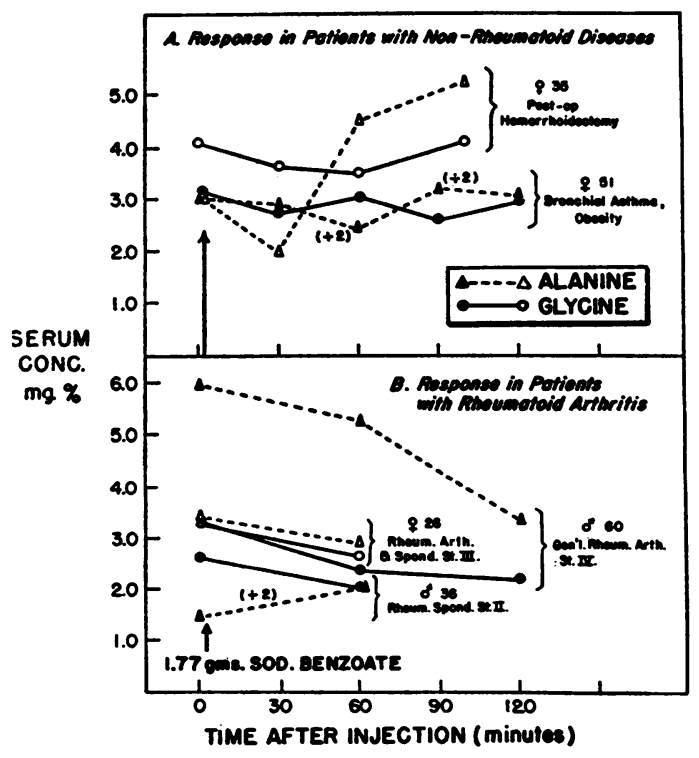

FIG. 1 
these patients examined on more than one occasion showed at some time a "positive" glycine response falling more than 15 per cent to levels, in some cases, less than 50 per cent of the initial values. When the total series of observations is classified according to the presence or absence of bone or joint involvement in both control patients and in rheumatoid arthritis cases, it is apparent that serum glycine lability is slightly increased in the presence of non-rheumatoid bone or joint pathology (Table III). The changes, however, are far greater in the rheumatoid patients who, in every stage of the disease, show highly significant increases in serum glycine response. This table also illustrates the normal hippuric acid excretion throughout all groups of patients observed; indeed, the Stage I rheumatoid cases show a barely significant increase in mean hippuric acid excretion compared with that of the entire control series. The $t$ value for this increase was 2.36 , corresponding to less than 1 chance in 50 of random occurrence. Statistical evaluation of the differences in glycine response indicates that they would occur by chance in less than 1 out of 100,000 trials. No significant differences in alanine levels were noted in either of these two groups of patients (32).

No significant abnormalities of liver function were detectable by laboratory examination in most patients in either the rheumatoid or control series. Infrequently, reduction in hippurate excretion, abnormal thymol turbidity, cephalin flocculation or inversion of the $\mathrm{A} / \mathrm{G}$ ratio was noted in patients with Stage IV arthritis. Renal insufficiency was not present in any of the cases in the series.

Among the rheumatoid arthritis group, serial determinations of serum glycine response to sodium benzoate administration and of sedimentation rates were frequently carried out. Fifteen patients were observed two or more times with an interval of two or more months intervening between blood samplings. In 11 patients, the sedimentation rate varied more than $10 \mathrm{~mm}$. per hour, and its changes correlated directly with the variation in glycine response to benzoate administration. An increase or decrease in the former was accompanied by a greater or lesser fall, respectively, in the level of serum glycine. In 3 patients, there was no detectable correlation, perhaps because there was less than $10 \mathrm{~mm}$. change in sedimentation rates in the interval. The last patient, Stage IV arthritic, showed wide fluctuations of serum glycine response independent of his sedimentation rate.

\section{DISCUSSION}

These observations reveal that patients with active rheumatoid arthritis cannot maintain a constant serum glycine level under the load imposed by intravenous administration of $1.77 \mathrm{gm}$. sodium benzoate. The data failed to show any corresponding disturbance in hippuric acid excretion, serum alanine concentration, or in hepatic or renal function. This manifestation of altered glycine metabolism has been noted in many Stage I rheumatoid arthritics previous to the development of deformity or roentgenographic abnormalities of bones and joints. It has been noted almost exclusively in patients in whom there were good clinical grounds for suspecting pathologic changes affecting collagen, including patients with active rheumatic fever and disseminated lupus erythematosus (19). Patients with inactive rheumatoid arthritis, inactive rheumatic fever, and discoid lupus erythematosus usually are able to maintain a serum glycine level within 15 per cent of the fasting level, similar to patients without organic disease, and those with hypertrophic osteo-arthritis only.

The decline of serum glycine from fasting levels noted in these patients might be explained by decreased reservoirs of pre-formed glycine in liver or peripheral tissues, by decreased synthesis of glycine, or by diversion of glycine from extracellular to intracellular pathways of utilization (Figure 2). Alteration in the function of enzyme systems controlling the distribution of bound glycine either in polypeptides or in some other form might contribute to the latter possibility. No differences have been noted in the mean daily glycine intake of rheumatoid and non-rheumatoid patients.

Glycine tolerance tests have failed thus far to establish an increased rate of glycine utilization in rheumatoid arthritis. Abnormally flat tolerance curves have been reported by DeVries and Alexander in one case (33), and by Stillman and associates in preliminary observations (34). In neither instance were the changes in these tolerance tests shown to be specific for glycine, and absent for other amino acids. Several groups of ob- 


\section{DIAGRAM OF PRINCIPAL METABOLIC UTILITATONS OF GLYCNE}

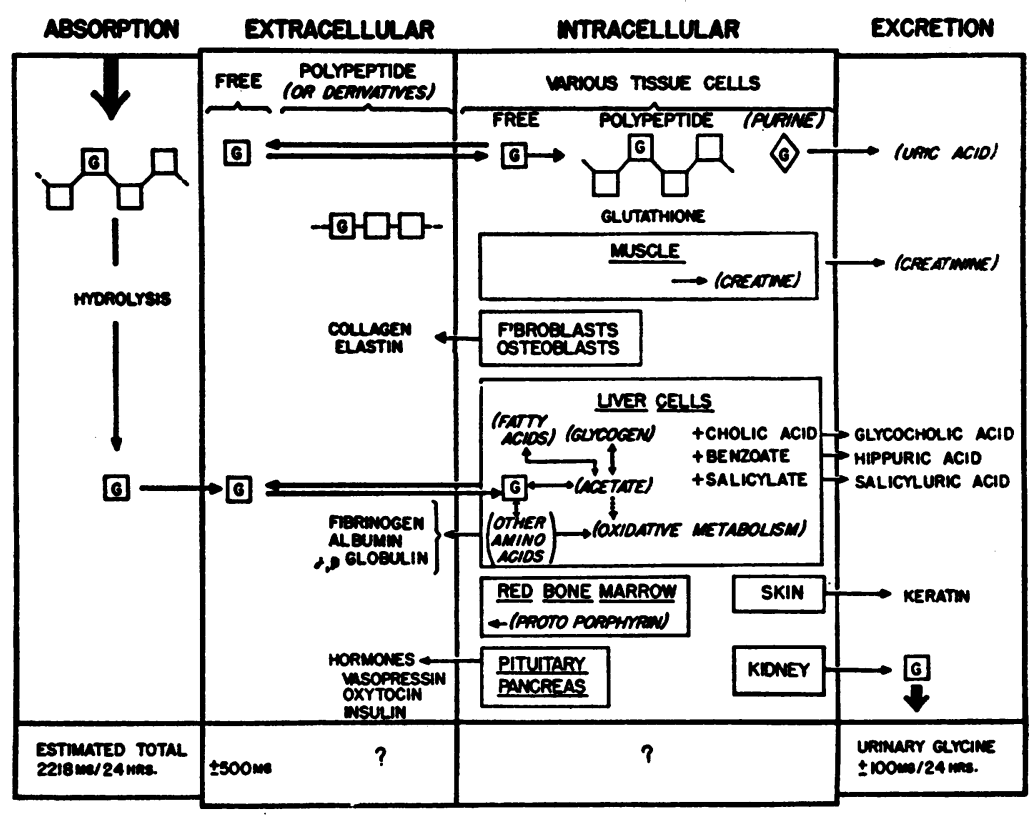

FIG. 2

servers have found no alteration in the fasting levels of glycine in rheumatoid arthritis patients compared to normals (32-34).

Hippurate synthesis is carried on at a normal rate in the Stage II to III arthritics, in spite of the decline of serum glycine. This suggests that the hepatic supply of glycine for detoxification is much the same in rheumatoid as non-rheumatoid subjects, since variations in glycine supply have a marked effect on the rate of hippurate synthesis $(35,36)$. Therefore, glycine deficiency in these patients, if present, is more likely to have taken place in extrahepatic amino acid depots, such as muscle, bone marrow, or epithelial tissues, if these findings are to be explained.

Many of the alternative processes utilizing glycine in rheumatoid arthritis appear to be depressed rather than increased (Figure 2). The presence of weight loss, anemia, hypo-albuminemia, muscular weakness and atrophy, cutaneous dystrophy (accompanying psoriatic skin manifestations), and cutaneous atrophy in advanced rheumatoid arthritis speak for reduced purine, hemoglobin, creatine, and keratin synthesis compared to normal. Only the synthesis of collagen appears to be increased in some of these cases, as a part of the reparative processes (37).
Both clinical and laboratory evidence therefore favor an extrahepatic source for the abnormalities noted in glycine metabolism in patients with rheumatoid arthritis and allied conditions. Further investigation is necessary to determine whether there are alterations in enzyme mechanisms releasing it to the blood stream, or using it for protein synthesis.

These observations of altered amino acid metabolism in rheumatoid arthritis have important etiologic and therapeutic implications that cannot be overlooked. Because of the uniquely small size of glycine residues, relative to those derived from other amino acids, the high concentrations of glycine in collagen and elastin have often been thought significant in influencing the characteristic configurations and modes of packing of the polypeptide chains in these fibrous proteins $(38,39)$. Failure of the supply of glycine to the periarticular fibroblasts would lead to impairment in production of normal collagen, or to the formation of abnormal collagen of poor quality. No analysis of the glycine content of diseased collagen has yet been made.

Excess free glycine administered parenterally or orally increases the rate of hippurate formation by the normal or diseased liver $(4,33,35,36)$. $\mathrm{Pa}$ - 
tients with severe manifest anxiety-reactions or normal individuals under severe stress excrete unusually large amounts of hippurate $(40,41)$. Many of our rheumatoid patients showed chronic anxiety, and the early cases in Stage I excreted more hippurate than did controls or those with more advanced disease (Table III). Severe emotional trauma superimposed upon chronic anxiety and insecurity is among the predisposing mental conditions favoring the onset of rheumatoid arthritis (42).

Re-evaluation of nutritional factors would appear to be important in the prevention and treatment of the rheumatoid group of diseases, not only because of these findings, but because of the limited daily intake of and synthetic capacity for glycine compared to its manifold pathways for utilization in essential processes (Figure 2). Although therapy with cortisone and ACTH delays the uptake of amino acids by rat cells (43), we have failed to note in our patients treated with these compounds any immediate improvement in abnormal serum glycine response. Spontaneous disease remissions, however, are often associated with return to a normal response curve.

\section{SUM MARY}

The administration of sodium benzoate to patients with active rheumatoid arthritis results in a decline of more than 15 per cent in the fasting level of serum glycine in the majority of cases, which persists for at least one hour. Similar changes have been observed in patients with active rheumatic fever and disseminated lupus erythematosus. Serum glycine remains constant in healthy persons or patients with hypertrophic osteo-arthritis. Because of the uniquely high concentration of glycine in collagen and elastin ( 22.8 to 27.6 per cent) and the fact that abnormal response of serum glycine to benzoate administration has been noted chiefly in diseases characterized by pathology of collagen, this test may be indicative of a metabolic abnormality affecting connective tissues. Evaluation of the response of serum glycine to benzoate administration may assist in the objective evaluation of patients with arthritic symptoms and in the earlier recognition of rheumatoid arthritis.

\section{REFERENCES}

1. Meyer, K., Smyth, E. M., Dawson, M. H., The isolation of a muco polysaccharide from synovial fluid. J. Biol. Chem., 1939, 128, 319.

2. Duran-Reynals, F., Tissue permeability and the spreading factors in infection. Bact. Rev., 1942, 6, 197.

3. Duran-Reynals, F., The ground substance of the mesenchyme and hyaluronidase. Ann. New York Acad. Sc., 1950, 52, 946.

4. Quick, A. J., The synthesis of hippuric acid: a new test of liver function. Am. J. M. Sc., 1933, 185, 630.

5. Bergmann, M., and Stein, W. H., A new principle for the determination of amino acids, and its application to collagen and gelatin. J. Biol. Chem., 1939, 128, 217.

6. Block, R. J., and Bolling, D., The Amino Acid Composition of Proteins and Foods; Analytical Methods and Results. C. C. Thomas, Springfield, I1linois, 2d ed., 1951, 338.

7. Almquist, H. J., and Mecchi, E., Glycine requirement of the chick. Proc. Soc. Exper. Biol. \& Med., 1942, 49, 541.

8. White, A., Growth-inhibition produced in rats by the oral administration of sodium benzoate. Effects of various dietary supplements. Yale J. Biol. Med., 1941, 13, 759.

9. Peters, J. P., and Van Slyke, D. D., Quantitative Clinical Chemistry. Williams and Wilkins, Baltimore, 2d ed., 1946, 1, 746, 799.

10. Rittenberg, D., and Schoenheimer, R., Studies in protein metabolism. VI. Hippuric acid formation studied with the aid of the nitrogen isotope. J. Biol. Chem., 1939, 127, 329.

11. Shemin, D., The biological conversion of $l$-serine to glycine. J. Biol. Chem., 1946, 162, 297.

12. Abbott, L. D., Jr., and Lewis, H. B., Comparative studies of the metabolism of the amino acids. VIII. Glycine precursors. Availability of $\mathrm{N}$ methylglycine, N, N-dimethylglycine, and betaine for the synthesis of hippuric acid by the rabbit. J. Biol. Chem., 1939, 131, 479.

13. Bloch, K., and Schoenheimer, R., The biological formation of creatine. J. Biol. Chem., 1940, 133, 633. The biological demethylation of sarcosine to glycine. J. Biol. Chem., 1940, 135, 99. The biological precursors of creatine. J. Biol. Chem., 1941, 138, 167.

14. Handler, P., Bernheim, M. L. C., and Klein, J. R. The oxidative demethylation of sarcosine to glycine. J. Biol. Chem., 1941, 138, 211.

15. Abbott, L. D., Jr., and Lewis, H. B., Comparative studies of the metabolism of the amino acids. IX. Glycine precursors. Availability of N-ethylglycine and glycolic acid for the synthesis of hippuric acid by the rabbit. J. Biol. Chem., 1941, 137, 535. 
16. Rawls, W. B., Weiss, S., and Collins, V. L., Liver function in rheumatoid (chronic infectious) arthritis. Ann. Int. Med., 1939, 12, 1455.

17. Hench, P. S., Bauer, W., Dawson, M. H., Hall, F., Holbrook, W. P., Key, J. A., and McEwen, C., The problem of rheumatism and arthritis. Review of American and English Literature for 1939. Ann. Int. Med., 1941, 14, 1383.

Hench, P. S., Bauer, W., Dawson, M. H., Hall, F., Holbrook, W. P., and Key, J. A., The problem of rheumatism and arthritis. Review of American and English Literature for 1937. Ann. Int. Med., 1939, 12, 1005, 1295.

18. Hepburn, J. S., Warter, P. J., and Rosenstein G., Liver function in arthritis, measured by the hippuric-acid test. Rev. Gastroenterol., 1943, 10, 126.

19. Lemon, H. M., Unpublished data.

20. Malloy, H. T., and Evelyn, K. A., The determination of bilirubin with the photoelectric colorimeter. J. Biol. Chem., 1937, 119, 481.

21. Rosenthal, S. M., and White, E. C., Clinical application of the bromsulphalein test for hepatic function. J. A. M. A., 1925, 84, 1112.

22. Shinowara, G. Y., Jones, L. M., and Reinhart, H. L., The estimation of serum inorganic phosphate and "acid" and "alkaline" phosphatase activity. J. Biol. Chem., 1942, 142, 921.

23. Schoenheimer, R., and Sperry, W. M., A micromethod for the determination of free and combined cholesterol. J. Biol. Chem., 1934, 106, 745.

24. Sperry, W. M., A micromethod for the determination of total and free cholesterol. Am. J. Clin. Path., 1938, Tech. Supp. 2, 91.

25. Howe, P. E., The determination of proteins in blood -a micro method. J. Biol. Chem., 1921, 49, 109.

26. Ley, A. B., Lewis, J. H., and Davidson, C. S., The quantitative determination of the thymol turbidity reaction of serum. J. Lab. \& Clin. Med., 1946, 31, 910.

27. Hanger, F. M., Serological differentiation of obstructive from hepatogenous jaundice by flocculation of cephalin-cholesterol emulsions. J. Clin. Invest., 1939, 18, 261.

28. Alexander, B., Landwehr, G., and Seligman, A. M., A specific micromethod for the colorimetric determination of glycine in blood and urine. J. Biol. Chem., 1945, 160, 51.

29. Alexander, B., and Seligman, A. M., A colorimetric method for the micro-determination of $\alpha$-alanine in blood. J. Biol. Chem., 1945, 159, 9.

30. Weichselbaum, T. E., and Probstein, J. G., Determination of hippuric acid in urine. J. Lab. \& Clin. Med., 1939, 24, 636.
31. Steinbrocker, O., Traeger, C. H., and Batterman, R. C., Therapeutic criteria in rheumatoid arthritis. J. A. M. A., 1949, 140, 659.

32. Looney, J. M., Lemon, H. M., and Chasen, W. H., Response of serum glycine and alanine in rheumatoid arthritis after sodium benzoate. Federation Proc., 1951, 10, 217.

33. DeVries, A., and Alexander, B., Studies of amino acid metabolism. II. Blood glycine and total amino acids in various pathological conditions, with observations on the effects of intravenously administered glycine. J. Clin. Invest., 1948, 27, 655.

34. Stillman, J. S., Comment on the "Effects of ACTH and Related Hormones on Amino-Acid Metabolism." Proceedings Second Clinical ACTH Conference. Blakiston, Philadelphia, Chap. 25, 1951, 1, 262.

35. Griffith, W. H., and Lewis, H. B., Studies in the synthesis of hippuric acid in the animal organism. V. The influence of amino acids and related substances on the synthesis and rate of elimination of hippuric acid after the administration of benzoate. J. Biol. Chem., 1923, 57, 1. VI. The influence of the protein of the diet on the synthesis and rate of elimination of hippuric acid after the administration of benzoates. Ibid, 1923, 57, 697.

36. Stern, K., Tyhurst, J. S., and Askonas, B. A., Note on hippuric acid synthesis in senility. Am. J. Med. Sc., 1946, 212, 302.

37. Rich, A. R., Hypersensitivity in Disease, with Especial Reference to Periarteritis Nodosa, Rheumatic Fever, Disseminated Lupus Erythematosus, and Rheumatoid Arthritis. Harvey Lect., 1946-1947, 106.

38. Bear, R. S., The structure of collagen fibrils, in Advances in Protein Chemistry, 1952, 7:69.

39. Pauling, L., and Carey, R. B., The structure of fibrous proteins of the collagen-gelatin group. Proc. Nat. Acad. Sc., 1951, 37, 272.

40. Persky, H., Grinker, R. R., and Mirsky, I. A., The excretion of hippuric acid in subjects with free anxiety. J. Clin. Invest., 1950, 29, 110.

41. Persky, H., Hippuric acid synthesis, plasma glycine level and tissue glutathione concentration in healthy persons under psychological stress. Federation Proc., 1952, 11, 268.

42. Ludwig, A. O., Psychiatric Studies of Patients with Rheumatoid Rheumatic Diseases, in American Rheumatic Association: Rheumatic Diseases. W. B. Saunders, Philadelphia, 1952, 112.

43. Sinex, F. M., Effect of the adrenal cortical hormones and insulin on alanine metabolism. Federation Proc., 1951, 10, 247. 